\title{
Officer and Director Stock OWNership \\ and Firm Performance in the Publicly Traded \\ Small Corporation
}

\author{
Catherine M. Daily \\ Ohio State University \\ Columbus, Ohio \\ Dan R. Dalton \\ Indiana University \\ Bloomington, Indiana
}

\section{Introduction}

Questions concerning the financial interests held by chief executive officers (CEOs) and boards of directors in the firms they serve has been a continuing topic of discussion and debate in the corporate governance literature (e.g., [26], [27]). It has been suggested, for example, that in order to ameliorate the costs associated with self-interested behavior on the part of management and board members, which is not necessarily isomorphic with that of shareholders, these individuals should be required to own substantial portions of the firm's stock ([3], [8], [25]). When these individuals possess significant personal financial interests in the firm, they are less prone to act opportunistically or behave apathetically with respect to firm performance, and are more prone to take an active interest in the financial well-being of the firm. Moreover, such equity interests may act to more closely align the objectives of corporate officers, board members, and shareholders.

Agency theory, for example, would suggest that the level of equity interest which individuals hold will directly influence the degree to which they are subject to selfinterested behavior, as opposed to firm-interested behavior [24]. The owner-entrepreneur, for example, will strive for profit maximization since firm profits accrue directly to this individual [30]. When organizational agents hold only a minor equity position in the firm, however, this incentive may be lacking, necessitating an increase in the monitoring of managerial actions [3]. Without monitoring mechanisms, the financial impact of poor decisions is borne by shareholders who are unable to directly sanction those making organizational decisions. Presumably, when the financial impact of organizational actions directly affects the financial status of those making the decisions, less monitoring will be necessary as organizational decision makers seek to improve firm performance to their direct financial benefit.

Legally, the board of directors is mandated to perform this monitoring function with respect to firm management, including the CEO [31]. As a governance body, the board has a fiduciary duty to protect shareholder interests. Moreover, the board is created to safeguard shareholders' interests from being exposed to excessive amounts of risk [52]. Unfortunately, boards are often negligent in this function. Many critics 
of boards of directors charge that, despite their legal responsibility to attend to the interests of the owners of the corporation (shareholders), directors seem unwilling or unable to challenge or constrain inappropriate managerial action ([16], [21], [37], [48]).

In response to the lack of careful monitoring, Kesner and Johnson [28] have recommended that directors become increasingly more active in corporate affairs. In theory, director ownership of the firm's stock should be accompanied by an increased incentive to closely monitor managers [50]. While the monitoring function of managers may be the most critical task of board members [51], it is often neglected.

Calls for increased monitoring of management by the board of directors are grounded, in part, in the need to monitor CEO behavior in particular. T. Boone Pickens, Jr., for example, has claimed that the biggest problem facing corporate America today is the lack of CEO ownership in the firms they serve [8]. Without ownership interest in the firm, CEOs are subject to self-interested behavior, often at the expense of shareholder interest. Pickens further argued that this "absence of financial risk is inconsistent with the free-enterprise system" [8]. As a result, both CEOs and board members should be required to maintain a financial interest in the firms they serve, in order to attenuate self-interested behavior and apathy. Such self-interest may manifest itself in the form of increased managerial salaries, extra staff, managerial shirking, and perquisites ([13], [35]).

\section{The Ownership-Performance Linkage}

Agency theory assumes that managers (agents) are often motivated to maximize their own utility, which often does not converge with that of the firm's owners ([17], [23], [24], [29]). In the corporate form of organization, executives are those managers with the power to direct the firm and the owners are the body of shareholders. When the agency problem exists, it is the owners of the firm who suffer the actions of the agents who may overlook the maximization of the shareholders' wealth [32]. The most obvious disadvantage of diffuse ownership, then, is the increased opportunity for managerial opportunism, at the cost of firm performance [17].

While extant research has generated conflicting results concerning the impact of ownership structure on firm performance, some support has been found for the proposition that stronger links between organizational agents and firm ownership result in improved firm performance. Krause [29], for example, found that among Fortune 500 firms, owner-controlled firms utilized their assets more efficiently, tended to grow at faster rates, and achieved significantly higher raw and excess returns than those firms under managerial control.

Additionally, Rumelt [46] found that in firms where CEOs perceive a strong connection between their personal financial stake in the firm and the wealth of the organization, the firm tends to be more profitable than when this linkage is absent. CEOs and board members, however, generally own relatively small portions of outstanding shares in the firms they serve ([20], [22]). Absent this linkage, it is the shareholder who endures the decline in equity value, not the managers responsible for the decisions. 
As ownership in the firm increases, managers are less likely to behave in a manner which detracts from firm value maximization [24]. This necessarily occurs because managers, then, bear the costs they incur when behaving in a manner which detracts from the augmentation of corporate wealth [35]. While ownership in the firm does not guarantee value maximization on the part of managers, it is certainly the more likely and rational outcome. Such arguments are predicated on a convergence-of-interests hypothesis [35].

Board members, in particular, may demonstrate a lack of concern regarding management decisions because "they run virtually no personal risk for any amount of complacency, cronyism, or outright neglect of their duties" [21]. In small firms this problem is further intensified by the small retainers paid to directors. Compensation paid for board service is so minimal as to provide little, if any, incentive to perform directoral functions effectively. Directors serving on small firm boards receive, on average, between $\$ 6,000$ and $\$ 8,000$ annually for their board service [38].

This situation may be further complicated in the small firm where control is a critical issue for CEOs. Founder CEOs in particular are more apt to exert control over firm operations, especially when personal financial interests are at issue ([6], [12], [45]). These CEOs, then, are resentful when directors presume to question their ability to effectively operate the firm. They prefer that the board not actively intervene [38]. This insistence for overarching control, however, may be a primary contributor to the ineffectiveness of founder-run companies [44].

In order to avoid the scrutiny of careful monitoring and evaluation of managerial actions, CEOs in small corporations may select board members who are sympathetic to the CEOs' opinions [6]. The implication is that only those who are willing to "rubber stamp" decisions will be invited for board service. Such directors are likely to be disinterested parties both unwilling and unable to serve as a necessary system of checks and balances to ensure effective management of the firm [49] and the protection of shareholder interests [52].

As a means for creating an incentive for directors to perform their monitoring function, board reform critics have suggested directors maintain a financial interest in the firms they serve. When directors own substantial portions of the firm's stock they are personally affected by the decisions and actions of top management ([26], [28]). It may, therefore, be particularly important for these individuals to possess large financial interests in the small corporation to effectively align personal and firm interests. Owner/directors may be willing to challenge and constrain management when it directly affects their financial situation [21].

Proponents of this theory include Muckley [36], Patton and Baker [40] and Pickens ([42], [43]). Their arguments include (1) the provision of strong leadership from someone who owns large amounts of stock [40], (2) dignifying the positions these individuals occupy through stock ownership [36]), and (3) the ability to relate to and act more like stockholders ([42], [43]). The outcome of these positions is increased shareholder value. The theory, however, has failed to receive widespread empirical support. 


\section{Hypotheses}

Despite calls for increased ownership in firms, the extant research suggests a lack of consensus for the proposition that increased ownership by organizational agents improves corporate performance by reducing agency costs [50]. While theory would suggest that if officers and directors own substantial amounts of stock in the companies they serve the firms will perform better, the empirical evidence is equivocal.

Kesner [26], for example, examined this financial dependence perspective among a sample of Fortune $\mathbf{5 0 0}$ companies. She found the amount of equity held by board members to be significantly related to several measures of financial performance, when controlling for industry growth. In low growth industries, board stockholdings were unrelated to firm performance; however, in high growth industries firms performed better when directors maintained a financial stake in the firm.

Alternatively, Chacko [8], in an examination of Fortune 500 firms, found "an utter lack of interdependence between company performance and the level of stock holdings by top management." Using net income and price/earnings ratio as dependent variables, and controlling for company size, he found no systematic relationship between management stock ownership and firm performance.

These mixed results may be attributable to the level of impact organizational agents may exert in large, complex firms. Both examinations relied on samples of large firms. As evidence of the need to examine smaller firms as well, several organizational scholars have suggested that in larger organizations the ability of CEOs to impact firm processes and outcomes may be constrained (e.g., [1], [14], [39]). It is in the smaller firm where organizational agents may be less constrained in their ability to directly impact firm actions. This study, then, examines the linkage between CEO and board of directors equity ownership (and effective control of the corporation) and financial performance in the context of the small corporation.

Much of the prescriptions aimed at improving the governance of corporations have been directed at board of directors composition (i.e., the inside/outside distinction). Vance [49], however, suggested that financial commitment to the firm in the form of stock ownership may have a greater influence on corporate performance than the inside/outside director issue. As a result, the financial impact of stock ownership by firm officers and directors is of interest to this study.

Maintaining control of the firm is a critical issue for CEOs of small firms. Typically, the owner-manager uses the business as a means for satisfying both professional and personal needs [38]. One means for exerting control is by holding the position of CEO and board chairperson concurrently (CEO duality). To do otherwise invites some risk of divided authority. To further entrench one's authority position, then, the CEO would elect to hold substantial portions of the firm's stock, particularly in the case of a founder-CEO.

H1: There will be a positive association between the incidence of CEO duality and CEO stock holdings. 
H2: There will be a positive association between founder-CEOs and CEO stock holdings.

Presumably, officers and directors in the firm would have some faith in the leadership of the organizations which they serve. As a consequence, these individuals would view CEO holdings in the firm as a sign of the CEO's confidence in his/her ability to effectively manage the firm and in the viability of the firm. Almost certainly the CEO would not maintain a large financial stake in a failing firm. This same rationale may be more salient when the CEO elects to hold the position of board chairperson as well.

H3: There will be a positive association between CEO stock holdings and officer and director stock holdings.

H4: There will be a positive association between CEO duality and officer and director stock holdings.

As previously suggested, CEO and officer and director stock ownership in the firm should serve to ameliorate self-interested behavior and align personal and firm interests to the direct financial benefit of the owners of the firm (shareholders). In line with the convergence-of-interests proposition [35], it is expected that as ownership stakes increase, firm performance will increase. This association will be particularly salient in the small corporation where organizational agents are more able to impact firm processes and outcomes. Morck, et al. [35], in particular, have called for research which specifically considers this ownership/firm performance linkage in the small firm.

H5: CEO stock ownership will be positively related to firm performance.

H6: Officer and director stock ownership will be positively related to firm performance.

Given the support presented in prior literature, all hypotheses have been presented in the alternative form. Past works have provided sufficient guidance to suggest the anticipated direction of the associations hypothesized.

\section{Methods}

\section{Sample}

A variety of definitions of what constitutes a small business have been offered (e.g., [1], [41]); however, d'Amboise and Muldowney [15] have suggested that the most commonly accepted definition of the small business for research and reporting purposes is that the business employs no more than 500 and does not have sales which exceed \$20 million per year. This definition, then, guided the selection of firms for 
the purposes of this study. Indeed, the 186 firms included in this study constitute all of the firms which meet this profile.

The publicly traded small corporations were selected from Standard \& Poor's Reports: Over-the-Counter \& Regional Exchanges and Standard \& Poor's Reports: American Stock Exchange. These sources were chosen based upon their comprehensiveness in reporting all corporations which fit the criteria for selection. Corporations are required to file documents with the Securities and Exchange Commission, and the data required to test the six hypotheses were available in these volumes.

\section{Variables}

CEO Duality: CEO duality is a binary variable; either the CEO concurrently holds the position of board chairperson or an independent individual holds this position. This information was obtained from the Standard and Poor's Register of Corporations, Directors, and Executives (1990).

Founder-CEO: Information concerning whether the CEO was also the founder of the corporation was determined through telephone interviews with representatives of the sample firms. Typically, the secretary/receptionist was able to provide this information. In some cases, however, the call was transferred to other parties (e.g., personnel office, public relations, office of the CEO) who were able to provide this information. All firms contacted provided the requested information.

Stock Holdings: The level of common stock holdings was also provided in the Standard \& Poor's sources. Common stock holdings for both CEOs and officers and directors of the firm were listed. Because the variable for officer and director holdings includes those holdings by the CEO, CEO common stock holdings were subtracted from this figure to obtain the aggregate common stock holdings of officers and directors of the firm, excluding the CEO.

Performance Indicators: Chakravarthy [9] has suggested that there currently is no agreement regarding the choice of an appropriate set of dependent variables to define corporate performance. Furthermore, Bourgeois [5] has noted that the selection of any given performance indicator creates a multiplicity of problems for the researcher, including quantification, dimensionality, validity, and universal acceptance. Selection of any one indicator, however, is likely to be deficient in capturing corporate performance for any given sample of firms. Accordingly, there have been several calls for the use of multiple indicators of performance (e.g., [7], [11], [33], [47]). When relying on performance as an outcome variable in examinations of small firms in particular, it is critical to use multiple measures of performance [4]. Reliance upon any single performance indicator will likely result in a biased view given that small business owner/ managers may operate based upon divergent goals.

Cochran and Wood [11] have noted that while any number of financial measures of firm performance are available, such measures can be classified into two broad categories: market measures and accounting measures. Both categories should be included in performance studies. Consequently, three commonly relied indices of fi- 
nancial performance, capturing both categories, were used in this study: return on assets (ROA), return on equity (ROE), and price/earnings ratio (P/E ratio). These data were collected from Standard \& Poor's Reports: Over-the-Counter and Regional Exchange and American Stock Exchange.

\section{Analyses}

Pearson product-moment correlation coefficients were relied on to test hypotheses one through four. These hypotheses suggest variables which are positively associated. Correlation coefficients measure the degree to which variables move in association with each other [10]; therefore, this statistical procedure provided an appropriate means to test the first four hypotheses.

For hypotheses five and six we rely on canonical correlation. These hypotheses each have three interrelated dependent variables (ROA, ROE, price/earnings ratio). Accordingly, the relationship between the independent variable and the three independent variables must be simultaneously assessed. Given that all variables for hypotheses five and six are interval, canonical correlation is the appropriate analytical technique. Because canonical correlation results can be subject to different interpretations we will provide both simultaneous and separate analyses for the dependent variables of hypotheses five and six.

\section{Results}

The six hypotheses consider the relationships between CEO duality, founder-CEOs, CEO and officer and director stock ownership, and firm performance. Hypothesis one posits an association between CEO duality and amount of common stock holdings. A pearson correlation provides support for this view $(r=.18, p<.01)$. Hypothesis two suggests a similar relationship between the founder-CEO corporate structure and equity holdings. The results indicate that this, too, is a viable hypothesis $(r=.26, p<.001)$.

Hypothesis three suggests an association between CEO stock holdings and officer and director stock holdings. Curiously, this association is not as hypothesized. The results indicate an inverse relationship ( $r=-.25, p<.05)$. Interestingly, large blocks of CEO equity are associated with lesser holdings by officers and directors. Hypothesis four is opposite as well. It seems that CEO duality/independence structures are inversely related to officer and director equity holdings $(r=-.31, p<.01)$.

The fifth hypothesis suggests that the level of CEO stock ownership will be positively related to firm performance. Given that we rely on three dependent variables to capture firm performance, we report here the results of a canonical correlation. Based on this analysis, there is no support for this hypothesis while considering the dependent variables simultaneously ( $F=2.01$, ns), or separately ( $R O A, F=3.82$, ns; $R O E$, $\mathrm{F}=.81$, ns; P/E Ratio, $\mathrm{F}=3.02$, ns).

The final hypothesis posits a relationship between levels of equity held by officers and directors and the financial performance of the firm. Once again in this case we rely on three dependent variables. A canonical correlation analysis indicates no 
support for this hypothesis either considering the dependent variables simultaneously ( $F=.22$, ns) or separately (ROA, F=.07, ns; $\mathrm{ROE}, \mathrm{F}=.52$, ns; P/E Ratio, $F=.36, \mathrm{~ns}$ ).

\section{Discussion}

The results are supportive of the tendency of CEOs, founder-CEOs in particular, to maintain control positions in the firms they serve. Among the firms sampled, CEOs holding the position of board chairperson and founder-CEOs both held higher levels of stock in the firm. By maintaining both an authoritative and equity position in the firm, CEOs decrease the likelihood of being challenged by the firm's officers and directors.

The results of hypotheses three and four may not be inconsistent with this view. From a control perspective (e.g., a CEO with large equity holdings or a dual CEO), that other officers or directors hold substantial equity positions in the firm may be interpreted as a threat. Given this, one would not be surprised, for example, if a CEO was not supportive of granting stock options to officers or directors. Failing this, a CEO may be influential in keeping such options at a modest level.

The results are also supportive of Chacko's [8] findings that there exists no significant relationship between top management's stock holdings and corporate performance. Additionally, the results did not distinguish between accounting returns or the market measure relied on in this study. One explanation may be that these measures are arguably short-term in their orientation. Perhaps expanding the variety of performance dependent measures to include those that capture more of a long-term orientation on the part of officers and directors of the firm would provide alternative results. Expenditures for research and development or advertising, for example, are suggestive of a long-term focus, as opposed to short-term indicators such as return on assets or return on equity.

The inability to link financial dependence and firm performance, based on agency theory arguments, may be the result of "gaping holes in the theory from the beginning" [8]. The belief that increased stock holdings by organizational agents would result in more careful management of the firm was based largely on conjecture and speculation [8]. Perhaps, such prescriptions are ill-informed.

Drucker [18], for example, has noted the benefits of having professional managers, as opposed to firm owners or family members, lead the corporation. He rejects the notion that large-scale stock ownership is a necessary condition for proper management of the firm. Chacko [8], in agreement with Drucker's observations, has noted that:

A corollary to the theory is that the stockholder with the largest holding should be seriously considered for the CEO's job. The qualities needed to lead the business organization of the future have little to do with the talent to amass and manage a huge personal fortune. 
Perhaps critics of professional management in the modern corporation have been too harsh in their judgment of the quality of leadership a firm receives when someone other than the owner is guiding the corporation. From the results of this study, it would seem that those individuals hired to oversee firm operations do so equally well regardless of the extent to which these individuals are financially tied to the firm. Given the impact that organizational agents may exert on the small firm in particular, these findings provide little promise for the dictate that the means for improving the performance of the firm is through financial dependence. Rather, the issue appears to be one of control.

Given that there are no financial gains which accrue when officers and directors hold stock in their firms, such holdings may be representative of the desire of these individuals to exert some control over firm operations. In the small firm in particular, CEOs have demonstrated a tendency to maintain tight controls over firm operations (e.g., [6], [13], [45]). Small firm owners bave been less than enthusiastic when firm outsiders presume to advise them on the management of their firms [38].

The unwillingness to accept advice includes the board of directors as well. CEOs tend to prefer an inactive board of directors who is less likely to monitor managerial actions ([2], [51]). Unfortunately, directors are often all too willing to accommodate this managerial preference. Outside directors, in particular, often lack the incentive or commitment to carefully monitor firm operations, especially CEO performance [19].

Additionally, a certain irony should be noted with respect to the board reform critics calling for increased stock ownership on the part of board members. If, in fact, board members did have an increased financial interest in the firm, it might be reasonably expected that their interests and those of the shareholders-the group they presumably represent-might converge. At the same time, however, the notion of "outside" direction would be lost. In general, one could hardly expect a director with a large equity stake in the firm to be a dispassionate observer. It might also be difficult to anticipate that a director would be independent of the very management which provided this largess.

Future research in this area, then, may benefit from an increased emphasis on the control dimension of stock ownership. It might be interesting, for example, to examine the relationships among CEO equity holdings and commonly operationalized factors in corporate control, e.g., CEO duality, board composition (proportion of outside directors), and number of outside directors. Some interdependence among such factorsin absence of systematic relationships with financial performance-might be interpreted as evidence of corporate control strategies.

\section{References}

1. Alcorn, P. Success and Survival in the Family-Owned Business. New York: MoGrawHill (1982).

2. Andrews, K.R. “Directors' Responsibility for Corporate Strategy." Harvard Business Review, Vol. 58(6) (1980), pp. 30-42. 
3. Beatty, R.P. \& Zajac, E.J. "Top Management Incentives, Monitoring, and Risk-bearing: A Study of Executive Compensation, Ownership, and Board Structure in Initial Public Offerings." Academy of Management Best Papers Proceedings, (1990), pp. 7-11.

4. Begley, T.M. \& Boyd, D.P. "Executive and Corporate Correlates of Financial Performance in Smaller Firms." Journal of Small Business Management, Vol. 24(2) (1986), 8-15.

5. Bourgeois, L.J. "Performance and Consensus." Strategic Management Journal, Vol. 1 (1980), pp. 227-248.

6. Brady, G.F. \& Helmich, D.L. Executive Succession: Toward Excellence in Corporate Leadership. Englewood Cliffs, NJ: Prentice-Hall, Inc., (1984).

7. Capon, N., Hulbert, J.M., Farley, J.U., \& Martin, L.E. “Corporate Diversity and Economic Performance: The Impact of Market Specialization." Strategic Management Journal, Vol. 9 (1988), pp. 61-74.

8. Chacko, C. "Management's Stock Ownership: Irrelevant?" Business Horizons, Vol. 33(3) (1990), pp. 75-78.

9. Chakravarthy, B.S. "Measuring Strategic Performance." Strategic Management Journal, Vol. 7 (1986), pp. 437-458.

10. Clover, V. \& Balsey, H. Business Research Methods. Columbus, OH: Grid, Inc., (1974).

11. Cochran, R.L. \& Wood, R.A. "Corporate Social Responsibility and Financial Performance." Academy of Management Journal Vol. 27 (1984), pp. 42-56.

12. Daily, C.M. \& Dalton, D.R. In press. "Founder Versus Non-founder Professional Management in the Small Corporation and Financial Performance." Journal of Small Business Management (in press).

13. Daily, C.M. \& Dollinger, M.J. In press. "An Empirical Examination of Ownership Structure in Family and Nonfamily Managed Firms.” Family Business Review, (in press).

14. Dalton, D.R. \& Kesner, I.F. "Inside/Outside Succession and Organizational Size: The Pragmatics of Executive Replacement." Academy of Management Joumal, Vol. 26 (1983), pp. 736-742.

15. d'Amboise, G. \& Muldowney, M. "Management Theory for Small Business: Attempts and Requirements." Academy of Management Review, Vol. 13 (1988), pp. 226-240.

16. Dayton, K.N. "Corporate Governance: The Other Side of the Coin." Harvand Business Review, Vol. 62(1) (1984), pp. 34-37. 
17. Demsetz, H. \& Lehn, K. "The Structure of Corporate Ownership: Causes and Consequences." Journal of Political Economy. Vol. 93 (1985), pp. 1155-1184.

18. Drucker, P.F. "The Coming of the New Organization." Harvard Business Review, (January-February) (1988), pp. 45-53.

19. Fleischer, A., Hazard, G.C., \& Klipper, M.Z. Board Games: The Changing Shape of Corporate Power. Boston, MA: Little, Brown, (1988).

20. Fosberg, R.H. "Outside Directors and Managerial Monitoring." Akron Business and Economic Review, Vol. 20(2) (1989), pp. 24-32.

21. Geneen, H. Managing. New York: Doubleday \& Co., Inc., (1984).

22. Herman, E.S. Corporate Control, Corporate Power. Cambridge, UK: Cambridge University Press (1981).

23. Hill, C.W.L. \& Snell, S.A. "Effects of Ownership Structure and Control on Corporate Productivity." Academy of Management Joumal, Vol. 32 (1989), pp. 25-46.

24. Jensen, M.C. \& Meckling, W.H. "Theory of the Firm: Managerial Behavior, Agency Costs and Ownership Structure." Journal of Financial Economics, Vol. 3 (1976), pp. 305-360.

25. Johnson, E.W. “An Insider's Call for Outside Direction." Harvard Business Review, (March/April) (1990), pp. 46-55.

26. Kesner, I.F. "Directors' Stock Ownership and Organizational Performance: An Investigation of Fortune 500 Companies." Journal of Management, Vol. 13 (1987), pp. 499507.

27. Kesner, I,F, \& Dalton, D.R. "Boards of Directors and the Checks and (Im)balances of Corporate Govemance." Business Horizons, (September/October) (1986), pp. 17-23.

28. Kesner, I.F. \& Johnson, R.B. "Crisis in the Boardroom: Fact and Fiction." Academy of Management Executive, Vol. 4(1) (1990), pp. 23-35.

29. Krause, D.S. "Corporate Control." Journal of Political Economy, Vol. 73(2) (1988), pp. 110-120.

30. Larner, R.J. Management Control and the Large Corporation. New York: Dunnellen Publishing Company (1970).

31. Louden, J.K. The Director: A Professional's Guide to Effective Board Work. New York: Amacom (1982). 
32. Masson, R.T. "Executive Motivations, Earnings and Consequent Equity Performance." Journal of Political Economy, Vol. 79 (1971), pp. 1278-1292.

33. Maupin, R.J. "Financial and Stock Market Variables as Predictors of Management Buyouts." Strategic Management Journal, Vol. 8 (1987), pp. 319-327.

34. McGivern, C. "The Dynamics of Management Succession: A Model of Chief Executive Succession in the Small Family Firm." Family Business Review, Vol. 2 (1989), pp. $401-411$.

35. Morck, R., Shleifer, A., \& Vishny, R.W. "Management Ownership and Market Valuation." Journal of Financial Economics, Vol. 20 (1988), pp. 293-315.

36. Muckley, J.E. “Dear Fellow Shareowner." Harvard Business Review, (March-April) (1984), pp. 46-64.

37. Nader, R., Green, M., \& Seligman, J. Taming the Giant Corporation. New York: W.W. Norton \& Company, (1976).

38. Nash, J.M. "Boards of Privately Held Companies: Their Responsibilities and Structure." Family Business Review, Vol. 1 (1988), pp. 263-269.

39. Norburn, D. \& Birley, S. "The Top Management Team and Corporate Performance." Strategic Management Journal, Vol. 9 (1988), pp. 225-237.

40. Patton, A. \& Baker, J.C. "Why Don't Directors Rock the Boat?" Harvard Business Review, (November-December) (1987), pp. 10-18.

41. Peterson, R.A., Albaum, G., \& Kozmetsky, G. “The Public's Definition of Small Business." Journal of Small Business Management, (July) (1986), pp. 63-68.

42. Pickens, T.B. Boone. Boston: Houghton Mifflin Co., (1987).

43. Pickens, T.B. "Takeovers: A Purge of Poor Managements. Management Review, (January) (1988), pp. 53-55.

44. Poe, R. "The SOBs." Actoss the Board-The Conference Board Magazine, Vol. 17(5) (1980), pp. 23-33.

45. Pondy, L.R. "Effects of Size, Complexity, and Ownership on Administrative Intensity." Administrative Science Quarterly, Vol. 14 (1969), pp. 47-60.

46. Rumelt, R.P. "Theory, Strategy, and Entrepreneurship." In D.J. Teece (Ed.), The Competitive Challenge: Strategies for Industrial Innovation and Renewal, Cambridge, MA: Bollinger (1987), pp. 137-158. 
Fall 1992 Daily \& Dalton: Stock Ownership \& Firm Performance

47. Shortell, S.M. \& Zajac, E.J. "Internal Corporate Joint Ventures: Development Processes and Performance Outcomes." Strategic Management Joumal, Vol. 9 (1988), pp. 527542.

48. Townsend, R. "Up the Board of Directors." Actoss the Board, Vol. 21(7) (1984), pp. 48-50.

49. Vance, S.C. Corporate Leadership: Boards, Directors, and Strategy. New York: McGraw-Hill (1983).

50. Walsh, J.P. \& Seward, J.K "On the Efficiency of Internal and External Corporate Control Mechanisms." Academy of Management Review, Vol. 15 (1990), pp. 421-458.

51. Wheelen, T.L. \& Hunger, J.D. Strategic Management. Reading, MA: Addison-Wesley Publishing Company (1990).

52. Williamson, O.E. The Economic Institutions of Capitalism: Firms, Markets, and Relational Contracting, New York: Macmillan (1985). 